\section{THE FOREFATHERS OF THE ENGLISH PEOPLE *}

THE English people of the present day present two types of physical structure, which are extremely different in their most marlsed forms, though they pass into one another by every shade of gradation. The one type is tall, fair-complexioned, yellow or red haired, and blue-eyed; the other, short, darkcomplexioned, black-haired, and black-eyed. The two types and their intermediate gradations are, at present, to be found side by side in most parts of the British Islands; but there is a marked predominance of the fair type in the eastern half of Britain. The languages spoken by the English people have, at the present time, no relation to these two physical types; English speakers and Celtic speakers belonging no less to the one type than to the other. Nor are the two Celtic dialects, Cymric and Gaelic, confined to people of the one or the other physical type, as both the types described are exhibited in their extreme forms among Welshmen, Highlanders, and Irishmen.

The earliest historical records of the nature of the population of Britain, furnished by Cæsar, Straloo, and Tacitus, take us back nineteen hundred years, and show that, at that time, the physical characters of the population might be clescribed in the same lan. guage as at present. The people of South-eastern Eingland and of Caledonia were certainly tall, fair, and blue-eyed, with hair varying from yellow to red in hue; while, in South Wales, they had dark hair and complexions, resembling the Spaniards of that day. But there was a wonderful difference in language between the ancient and the modern inhabitants of these islands, inasmuch as all these people of Britain, so far as we know, spoke the Cymric dialect of the Celtic tongue; while it is probable, though we have no absolute knowledge on this point, that in Treland they spote Gaelic. Thus, at the time of the Roman invasion, the outward physical characters of the population of these islands were much what they are now, though the language spoken was, probalily, altogether Cellic. And there was no parity between the distribution of the Cymric and Gaelic dialects of the Celtic and that of the two physical types, any more than there is now between English and Celtic and the fair and dark stocks by which those languages are spoken. If we confine our attention to the I3ritish Islands, therefore, we have absolutely no means of ascrib. iing any special physical characters to the Celtic-speaking people. A British, or Irish, "Celt" might be tall or short, dark or fair, rounded-headed or long-headed; and the remark of Professo Max Miiller that it is as rational to speak of a dolichocephalic langurge as of a Celtic skull is, for the "Celts" of Britain, perfectly justified.

Whence was this Celtic-speaking people, with its two contrasted dark and fair forms, which inhabited Britain nineteen hundred years ago, derived? The position of the British Islands is sufficient to suggest the extreme probability that it migrated from Europe, the eastern and the southern faces of these islands being within easy reach of the shores of those countries which are now Norway, Denmark, North Germany, Holland, Belgium, and France. And the probability suggested by the facts of geography becomes converted into a certainty by those of ethnology and of history.

In the first place, if we turn to the existing population of the continent of Europe and Asia, we shall at once recognise our two physical types - the fair and the dark. From Norway to North-eastern France the predominant constituents of the riverain population of the North Sea and of the British Channel are tall, fair-haired, and blue-eyed. In North-westem France the proportion of short and dark people increases, until, in Southern and South-western France, they are the chief constituents of the population. A traveller who should set out from the Orkney Islands and call at every port in the North Sea, and who then should make a land journey from the mouth of the Elbe to that of the Don, wonld find the people with whon he met to be genernlly, and in many regions exclusively, of the fair type. On the other hand, if he set out from Galway and crnised along the western coasts of these islands, and of France and of Spain and the north shore of the Mediterranean, he would find as marked a predominance of the dark type. In fact, the population of the southern and western parts of France, of Spain, of the Ligurian shore, and of Western and Southern Italy, is as generally dark as that of North Germany is fair.

There is no reason to think that climatal conditions have had anything whatever to do with this singular distribution of the * A Lecture delivered by Prof. Huxicy, in St. George's Hall, on Sunday, M. Iaxch $\geq 3$, and reviscd by the avthor. fair and the dark types. Not only do the dark Celtic-speakers of the Scotch Highlands lie five or six degrees farther north than the fair Black-foresters of Germany; but, to the north of all the fair inhabitants of Europe, in Lapland, there lives a race of people very different in their characters from the dark stock of Britain, but still having black hair, black eyes, and swarthy yellowish complexions.

Thus, having regard only to physical characters, the population of Europe falls into three broad bands, which run in a rough way from west to east. In the north is the zone of the blackhaired, black-eyed Mongoloid Lapps. In the south is the zone of the people who resemble the dark type of the British Islands, and who have been called Mclonochiroi; between them lies the broad belt of fair people, who have been termed Xanthochroi. And if this were a mere natural history question, the facts $I$ have mentioned would allow us to draw but one conclusion as to the origin of the population of these islands-namely, that the clark type has been furnished by immigrants from the Continental Melanochroi; the fair type by immigants from the Continental Xanthochroi. But listory and philology have every right to be heard in such a matter as this ; and I must now try as well as I can (for I am neither historian nor philologer) to put before you what they have to say.

What history tells us, so far as it goes, is quite in accordance with the suggestions of biology. It is certain that, from the fifth century to the tenth a vast number of people from North Germany and Scandinavia poured into the British Islands on all sides, but, as might be expected, most persistently and numerously into the eastern moiety of Britain. They brought with them languages which may properly and conveniently be termed dialects of Teutonic, in contradistinction to the indigenous dialects of Celtic. Out of the North German dialects the language usually known as Anglo-Saxon was cleveloped, and from it, by subsequent modification and absorption of, for the most part, Scandinavian, Celtic, and French elements, has grown English. The invasion which thus changed the language of Inritain introduced no new element into the physical conformation of the people, so far as stature and complexion are concerned, though it may lave done so in the matter of cranial conformation. It is unquestioned that Saxons, D.mes, and Norsemen were alike a tall, fair-haired people; and their immigration strengthened the Xanthochroic element of our population, but added nothing new, unless it were a longer form of head. It is a very remarkable circumstance that the skulls of the existing Scandinavians-and of the Allemanni and Saxons, if not of the whole of the ancient Germans-are long, while those of the South Germans and Swiss of the present day, and those which very probably belonged to the ancient Belga, are round. Thus, to put the matter in another way, tall stature, fair hair, and blue eyes, in a native of Britain, are no evidence of his descent rather from the primitive Celtic-spealsing, than from the immigrant Teutonic-speaking, element of our population; or the reverse. He is as likely to be a "Celt" as a "Teuton;" a "Teuton" as a "Celt."

But history teaches us more than this. There is the clearest evidence that the Gauls-the Celtic-spealsing people who burnt Rome nearly foux centuries before our era-belonged to the fair type, and neither by their stature, their complexions, the colour of their eyes or their hair, were distinguishable from such Tettonic-speaking people as the Goths, who sacked Rome four centuries after it: and that, for these eight centuries at any rate, North-western, Central, Eastern Europe, and the western part of Central Asia were occupied by a tall, fair, blue-eyed people* who were known by the names of Celtre, Belgre, Germani, Venedi or Wends, and Alani, according to the districts which they occupied and the languages which they spoke. $t$

Thus, when history first makes known the Celtic language to us, it is in the mouths of a people extremely similar in their outward appearance to the Germans and the Slavonians; and when the affnities of the Celtic, the Teutonic, and Slavonic languages are worked out by the philologer, they are all found to belong to the same great group of Aryan languares. The argument to be drawn from the physical affinity of the Celtic-speaking with the

* The story told by Suetonius, that Caligula tried to pass off some tall Gauls for Germans, by inaking them redden their hair, is often quoted to prove that the hair of the Gauls difiered fiom that of the Germans. Wut as the Germans themselves were in the habit of reddening their hair artificially, the force of the argument does not appear.

t Thase who have any doubts upon this subject had better consult the great work of Kaspar Zeuss, "Die Deutschen ünd die Nachbarstämne," published thirty years ago; or the excellent discussion, mainly based upon Zeuss, in Pritchard; or the instructive essays of Brandes and De Belloguet. 
Teutonic-speaking people is therefore supported and intensified by the linguistic affinities between the Celtic and the Teutonic tongues; and philology concurs with history in testifying to the ethnic unity of the Celtic-speaking people on the left bank of the Rhine, with the Teutonic-speaking * people to the eastward. In their clothing, in their arms, in their houses, in their employment of horses and wheeled carriages, no differences of moment obtain between the Celtic-speaking and the Teutonic-speaking people of old Europe ; nor in their fashion of government, their social organisation, their morality, + or their theology, do there seem to be any greater differences than are readily accounted for by the fact that the Teutonic-spealing nations were more remote from the corrupting influences of wealth and civilisation. The Tonga islanders of Mariner's time offered the same contrast to the 'Tahitians that the Germans of Tacitus do to the Gauls, but no one would dream, on that ground, of declaring them to be of different races.

Hence, there can be no reasonable doubt, that the fair element of the Celtic-speaking population of these islands 1,900 years ago was simply the western fringe of that vast stock which can be traced to Central Asia, and the existence of which on the confines of China in ancient times is testified by Chinese annalists. Throughout the central parts of the immense area which it covers, the people of this stock speak Aryan languagesbelonging, that is, to the same family as the old Persian or Zend, and the Sanskrit. And they remain still largely represented among the Affighans and the Siahposh on the frontiers of Persia on the one hand, and of Hindostan on the other. But the old Sanskrit literature proves that the Aryan population of India came in from the nortl-west, at least 3,000 years ago. And in the Vedas these people portray themselves in characters which might have fitted the Gauls, the Germans, or the Goths. Unfortunately there is no evidence whether they were fair-haired or not.

India was already peopled by a dark-complexioned people more like the Australians than anyone else, and speaking a group of languages called Drawidian. They were fenced in on the north by the barrier of the Himalayas; but the Aryans poured from the plains of Central Asia over the Himalayas, into the great river basins of the Indus and the Ganges, where they have been, in the main, absorbed into the pre-existing population, leaving as evidence of their immigration an extensive modification of the physical characters of the population, a language, and a Iiterature.

Italy is to the Alps what Hindostan is to the Himalayas. The Po is its Ganges. Four centuries IB.C. it was peopled mainly by the clark and short stock represented by Ligurians, Etruscans, and old Italians. The Gauls poured into it over the north western passes, and settled in Cis-Alpine Gaul, modifying the physical characters and the language of the population, but becoming lost eventually in the great Roman nationality. And, doubtless, in more ancient times, the Aryan-speaking ancestors of these Celtre and Belgex had similarly made their way through the Hercynian forest or along the shores of the North Sea, into Gaul, and thence into Britain. The correspondence of the names of places in Gaul and ancient Britain fully confirms Cæsar's statement that the Belgic Gauls had, at some comparatively recent time, colonised south-eastern Britain in great numbers. But the primitive colonisation of Britain from the mainland by the fair people is doubtless of extreme antiquity.

I have now, I believe, accounted for the fair Celtic-speaking population of ancient Britain. There remains the problem Why did Britain contain another Celtic-speaking population, of a totally different type?

The key to this riddle is, I believe with $D_{\text {r. Thumam, }}$ De Belloguet, and others, afforded by history and philology. History, which tells by the mouths of Cresar, Strabo, and Tacitus, that the Aquitani, who lived beyond the Garonne, were a small and dark people like the Iberians, who spoke a language different from that of Gaul. Philology, which tells us that this language was the Euskarian, represented by the modern Basque, which is unlike every other European language, and which once covered a vastly greater area than it now occupies-the great majority of the people who once spoke it having acquired other languages.

* I use this phrase without prejudice to the much-debated question, Did the Germans of Cæesar and Tacitus speak "Deutsch" (not 'Dutch," pace Mr. Freeman or Celtic? and with the greatest respect for the champions of both "Keltenthun" and "Deutschthum." It is enough for me if nobody doubts the "Deutschheit" of the Goths and Alemanni.

t The grossest immorality with which the Gauls are charged may well ef Massilia along with other products of Greek civilisation.
Thus, once more, physical and philological ethnology properly viewed, concur. The plysically distinct stock turus out to be linguistically distinct-to have, in fact, all the ethnological characters of a distinct race.

In Spain, and within the boundaries of the old Aquitania, the Euskarian language lingers only among a frasment of the population, though the Spaniards and southern Frenchmen retain, to a great extent, the dark complexion and short stature of the Melanochroic stock. In Britain the same process of extinction seems to have been consummated as far back as the time of Tacitus. For from what has been said, it can hardly be doubted that the Silures and the dark type in general were the outliers of the continental Euskarian-speaking dark type, just as the British Belgae, and the fair type in general, were the offshoots of the continental Celtic-speaking fair type. And just as in Western and Middle Gaul, and in Spain, the Celtic-speaking fair people had, even in the time of Cresar, largely supplanted and absorbed the dark stock ; so, in Britain, it is to be supposed that it had altogether absorbed it, and that the dark stock had given up their Euskarian for the Celtic language.

All these reasonings may be put into the form of a probable hypothesis, as follows:-The chain of the Alps, the densely wooded highlands of Central Europe known in old times as the Hercynian forest, and the broad Rhine in its lower course, form a natural rampart between the vast central plains of Eurasia and Western and Southern Europe. Before England was peopled by the ancestors of its present population, the latter region, including the north shore of the Mediterranean, Spain, and Gaul (and perhaps the shores of the Baltic) were occupied by people of the dark type, who may, by possibility, have been the chief people of the so-called bronze age in those parts. These people occupied the British islands wholly or in part, and were, very probably, at first their sole occupants. And in Spain, France, and Britain they spoke Euskarian dialects.

During this time the fair stock, with its Aryan languages, wandered over the great Eurasiatic plain to the east of the rampart, from Poland to the frontiers of China, and from Siberia to those of Persia and India. But at length the fair people found their vast plains too narrow, or the luxuries beyond its natural barriers too tempting, and they began to overflow-as Celtic-speakers into Western Europe ; as Zendic and Sanskritic speakers into P'ersia and Findostan. The Celtic-speaking fair people, passing into Gaul, partly extirpated and partly mixed with the pre-existing dark Eiuskarian-speaking population, imposing their language and habits on all the northern, middle, and eastern parts of Gaul, and extencling widely into Spain. From Gaul they passed into Britain, and Celticised it still more completely; so that, though much of the old blood of the dark stock remained, its language vanished.

The Teutonic-speaking people were simply another wave of the same great Aryan ocean of Central Eurasia. They treated the Celtic-speakers exactly as the latter had treated the dark stock, and before another century has passed the Celtic language will probably be as much a thing of the past in these islands as the Euskarian is.

If this is a fair picture of the general course of events, it furnishes the explanation of the fact from which we started, namely, the presence in the British Islands of two distinct ethnical elements-a fair and a dark.

T. H. HUXLEY

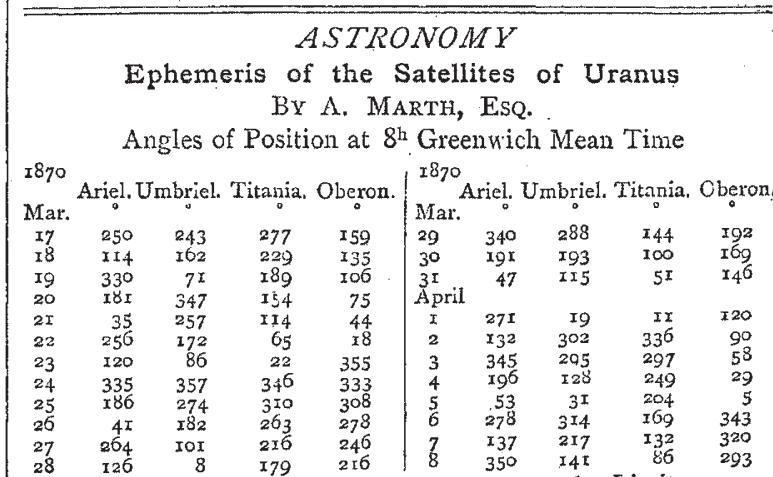

The Apparent Distances vary between the Limits.

$\begin{array}{llcc}\text { Ariel } & 15^{\prime \prime} & \text { and } & 12^{\prime \prime} \\ \text { Umbriel } & 22^{\prime \prime} & " & 16^{\prime \prime} \\ \text { Titania } & 35^{\prime \prime} & \# & 27^{\prime \prime} \\ \text { Oberon } & 4^{6 \prime} & \# & 36^{\prime \prime}\end{array}$

